\title{
15 E-gOVERNMENT AND CHANGES IN THE PUBLIC SECTOR: The Case of Greece
}

\author{
Dimitra Petrakaki \\ Lancaster University \\ Lancaster, U.K. \\ Wolverhampton Business School \\ Wolverhampton, U.K.
}

\begin{abstract}
During the past few decades, many governments around the globe have orchestrated e-government projects in order to improve the way they operate and provide public services to citizens. Apart from the opportunities they open up, e-government projects bring about changes in the well-established practices of the public sector. This paper illustrates some of these changes by exploring a Greek e-government initiative. As the case illustrates, e-government requires an output orientation and business-like behavior from officials, enables constant electronic control, and leads to the standardization of official's knowledge. Drawing upon these changes, we propose a framework of the transformations that e-government brings about in the work roles, nature of work, forms of knowledge, modes of control, and source of accountability of officials.
\end{abstract}

Keywords E-government, public sector change, power, performance, standardization

\section{INTRODUCTION}

During the past few decades, many governments around the globe have reformed the ways in which they operate and provide services to citizens. These reforms have been influenced by ideas incorporated in the electronic government agenda. E-government emerged in the 1990s with the aim of harnessing the benefits of the deployment of information and communications technologies (ICTs) to the public sector. ICTs mediate at two levels: they are used internally, for the reorganization and streamlining of

Please use the following format when citing this chapter:

Petrakaki, D., 2008, in IFIP International Federation for Information Processing, Volume 267, Information Technology in the Service Economy: Challenges and Possibilities for the $21^{\text {st }}$ Century, eds. Barrett, M., Davidson, E., Middleton, C., and DeGross, J. (Boston: Springer), pp. 213-227. 
government procedures (Hazlett and Hill 2003; Moon 2002; Vintar et al. 2003), and they are deployed so as to improve public service provision, enable citizens' interactions with government, increase citizens' awareness about government's function and results, and to achieve accountability and transparency (Basu 2004; Gil-Garcia et al. 2007; Kumar and Best 2006; Martin and Byrne 2003; Moon 2002; Vintar et al. 2003; von Haldenwang 2004; Zhang 2002). Frequently, e-government projects are orchestrated by the best practices of the private sector, such as process reengineering, performance measurement, contractualization, and establishment of internal markets (Bloomfield and Hayes 2004; Ciborra 2003; Hoggett 1996; Hood 1991; Tan and Pan 2003; Vintar et al, 2003). The adoption of the best practices of the private sector is thought to eliminate many problems of the public sector such as red tape, time lags, irresponsiveness, and unaccountability (Clarke and Newman 1997; du Gay 2000; Farrell and Morris 2003).

E-government, however, is not reduced to the managerial and information technologies that typically drive its implementation (Hazlett and Hill 2003; Vintar et al. 2003). Rather, its initiation presupposes, to a major or lesser extent, the organization and reorganization of the policies, practices, and procedures that surround the function of the public sector (Cordella 2007). In that way, e-government opens up opportunities for improvements in the function of the public sector but at the same time challenges the regulatory, historical, normative and socio-cultural context within which it emerges.

The aim of this paper is to illustrate some of these changes and challenges by drawing upon a Greek e-government initiative, Citizens Service Centers (CSCs). CSCs were developed as one-stop shops that mediate between citizens and public organizations for the quick and continuous service of citizens. Drawing upon the Greek case, the study illustrates the type of changes that surround e-government by placing specific focus on the practices of officials. The paper is structured as follows: The next section tracks the changes that e-government conditions on the public sector. The methodology that underpinned the research process is presented, followed by presentation of the case. First, we provide an account of the historical construction of the Greek public sector. Next, we present the establishment of CSCs and the transformations that accompanied it. In section five, we discuss the changes that e-government brings about in officials' practices. The paper ends with some concluding remarks.

\section{THEORETICAL FRAMEWORK: E-GOVERNMENT AND THE PUBLIC SECTOR}

In this section, we first present the ideal type of organization for the public sector by drawing upon Weber's (1948) work. Next, we revise the literature on the function of one-stop shops in e-government initiatives. The section ends with a presentation of previous studies on the changes that e-government brings about to officials' work practices.

\subsection{From the Bureaucratic Public Sector to E-Government}

The Weberian bureaucracy (Weber 1948) constitutes an iconic example of the organization of the public sector. In its ideal form, the Weberian bureaucracy is condi- 
tioned upon certain principles. First, it is comprised of offices (the bureau) each of which has certain designated jurisdictions and specific legal rules and regulations, which officials are responsible for knowing and abiding (Weber 1948). The law constitutes, in this case, officials' form of expertise and government's source of power against which officials' practices are evaluated (Campbell 1993; du Gay 2000; Goodsell 2005; Minson 1998). Second, the hierarchical structure of bureaucracy indicates differences in status, expertise, and jurisdictions and illustrates authority relations of super and sub-ordination (Clark and Newman 1997). Third, the position in the hierarchy is the source of officials' responsibility. Specifically, officials are loyal to their superiors and liable for their subordinates' actions (Blau 1970; Campbell 1993; Goodsell 2005; Minson 1998; Weber 1948). Fourth, the Weberian bureaucracy presupposes impersonality. Officials are disconnected from the authority that their job position entails and obstructed from using the bureau in opportunistic ways (Weber 1948).

Despite its rigid and often dehumanizing principles, the Weberian bureaucracy constitutes a virtuous forms of organization (du Gay 2000; Weber 1948). This is because impersonality, adherence to rules, and abstinence from personal emotions eliminate discrimination and favoritism, obstruct opportunistic behaviors, and ensure equal and democratic public service provision (Blau 1970; Clarke and Newman 1997; du Gay 2000).

Yet, the principles of the Weberian bureaucracy are ideal and not essential. Bureaucracies vary according to the context within which they emerge. For that reason, their function is often perceived as being ineffective, inflexible, and surrounded by illegal phenomena such as corruption and bribery. It was within this context that e-government emerged, with the hype to engender accountability and effectiveness in the public sector.

\subsection{One-Stop Shops in E-Government}

E-government is perceived as being a trigger for change, yet it serves different purposes and is differently deployed in each country (Yildiz 2007). This study focuses on the e-government initiatives in which one-stop shops are used as governmental access channel (Chadwick and May 2003) or intermediaries (Heeks 2002) between citizens and public officials.

In the e-government literature, one-stop shops are presented as single points, either geographical or electronic (e.g., portals, central/local government websites), where government departments integrate for public service provision (Ho 2002; Illsley et al. 2000; von Handenwang 2004). Citizens typically turn to them in order to submit all of their, administrative in nature, requests quickly and at no cost (Cowell and Martin 2003; Ho 2002; Illsley 2000; Lenk 2002). One-stop shops are, therefore, intended to substitute, with a single contact point, the multiple transaction points that citizens have with the public sector. In that way, they also dissolve heterogeneity and differentiation in public service delivery (Huang and Bwoma 2003; Martin and Byrne 2003; Tan and Pan 2003).

One-stop shops take various forms. They can be shops that provide multiple services from a single point or access points that bring together multiple organizations (Illsley et al. 2000). In their ideal form, one-stop shops are organized in a front and back office. The front office is responsible for coming in contact with citizens and submitting any requests or enquires they might have. The back office is liable for processing citizens' information. 
The establishment of one-stop shops presupposes elimination of departmental and organizational boundaries and reorganization of public administrative procedures in accordance with citizens' needs (Kunstelj and Vintar 2004). Technologies such as business process reengineering and customer relationship management are frequently deployed in order to achieve these purposes (Bloomfield and Hayes 2004).

The one-stop shop approach in public service delivery is supposed to lead to efficiencies because it enables fast, integrated, and customer-oriented public service provision (Illsley et al. 2000; Kunstelj and Vintar 2004; Roche 2004). Also, it engenders transparency in the function of the public sector by drawing clear lines of responsibility between the front and back office staff (Wilkins 2002). It is in that sense a general method of improving public service delivery rather than a technique that is solely adopted in e-government initiatives. The rest of the section focuses on the changes that one-stop shops in e-government initiatives and e-government initiatives in general condition in the work practices of public officials.

\subsection{E-Government and Changes in the Public Sector}

Many studies report the failure of e-government initiatives to engender transformations in officials' work practices. Some of these failures lie with officials' reluctance to perceive the beneficial impact of IT on their work practices (Gil-Garcia et al. 2007), heterogeneous and incompatible information systems (Ciborra 2005), and the "silo mentality" that conditions departmentalism (Bloomfield and Hayes 2004; Davidson et al. 2005; Turner and Higgs 2003).

Of the studies that have accounted for the changes that e-government triggers in the public sector, some focus on issues of power and politics. Specifically, Purnendra (2002) argued that e-government provides autonomy to officials by allowing them to access, manage, and process information. Also, according to Purendra, e-government imposes on officials the imperative for extensive use of ICTs and conditions fears and anxieties that come from the computerization of officials' work and the possibility for downsizing. Further, according to Zhang (2002), e-government provides the potential for exercising electronic forms of surveillance over officials' work. Specifically, by centralizing information in public networks, governments control at a distance both the type of information that is made accessible and the people who are eligible to access it. This allows governments to intervene, take corrective actions, and exercise sophisticated power. Moreover, Davison et al. (2005) illustrated that the transition from government to e-government requires public officials to develop new capacities. Officials, for instance, are asked to improve their performance by sharing their knowledge with colleagues and accelerating the processing of information and the provision of public services.

On the other hand, Bovens and Zouroudis (2002) claimed that e-government transforms officials from "street-level bureaucrats" to "system level bureaucrats." Specifically, e-government creates three types of civil servants: those who process data, those who communicate with citizens (interface staff), and those who manage the whole process. Further, they argued that e-government initiatives presuppose the codification of laws, reducing in that way officials' autonomy and freedom to exercise their discretion. Also, according to Cordella (2007), e-government draws upon the new public management agenda in order to impose managerial practices on officials' work. 
Furthermore, Kumar and Best (2002), who studied the establishment of a one-stop shop in India, pinpointed three changes in officials' work practices. First, the one-stop shop reduced the direct contact that officials had with citizens. Second, officials were obliged to use new technology without getting appropriate training. Third, officials lost their freedom to decide how, when, and to whom public services are provided. This type of decision making was now displaced to the staff who worked in this one-stop shop Internet kiosk. The latter also diminished officials' opportunities for corruption and obstructed their rent-seeking behavior.

Despite these interesting conclusions, e-government studies have neglected to account for how e-government influences the historically shaped practices of officials. This methodological omission obstructs, in turn, our further conceptualization of the changes that surround e-government projects (Heeks and Bailur 2006). The paper will track these changes by examining a Greek e-government project within the historical context of the Greek public sector.

\section{RESEARCH METHODOLOGY}

The research drew upon the qualitative paradigm and particularly social constructionism (Berger and Luckman 1966). According to this paradigm, social phenomena are constructed by various discourses and material artifacts. These in turn are accompanied by cognitive and normative aspects that, when adopted, construct subjectivities, guide the conduct of individuals, and reproduce the institutions within which they are created (Berger and Luckman 1966, p. 111). The cognitive aspects define the roles and responsibilities we undertake, for instance, as parents, spouses, and employees. The normative aspects indicate the "right" behaviors we are expected to internalize and the "wrong" to avoid in order to be accepted as legitimate members of the reality of which we are a part. The adoption and reproduction of these cognitive and normative aspects render institutions legitimate and unquestioned (Suchman 1987). In accordance with that, this paper will consider e-government as an initiative that is socially constructed through the deployment and reproduction of various managerial and technological means and discourses.

The research was conducted with the use of interviews and observation along with document collection. Particularly, we reviewed laws concerning public administration from the 1950s until the present, governmental regulations about CSCs' function and their collaboration with public organizations, newspaper articles on public administration along with government documents that were produced by the Ministry of Interior, Public Administration and Decentralization (MIPAD) such as presentations and reports. We also reviewed the Greek sociological literature in order to account for how the Greek public sector has historically been constructed.

The research project was carried out in three periods. The first was between October and December 2005, the second between March and May 2006, and the last in August 2006. The first period was mainly but not exclusively devoted to interviewing and observing. We interviewed officials from the Greek MIPAD, two politicians, who were implicated due to their position in the regulation of CSCs, the vendor who implemented and maintains the technological platform for the CSCs, and supervisors and staff of the CSCs and made observation of the latter's daily practices. Interviews were semi- 
structured, recorded, and lasted, on average, for an hour. In some cases, second interviews were conducted. The second and third period were mainly devoted to the observation of CSCs' staff's collaboration with civil servants from various public sector organizations and interviews with civil servants. We visited five CSCs located in the two biggest cities in Greece. In order to understand how CSCs functioned, we observed their practices for at least four hours a day, each day, for a period of two months. In parallel with the observations, we held discussions with CSCs staff when they were dealing with citizens and also during their breaks. Notes of these discussions were recorded in a diary.

Interview transcripts, research diaries, and documents were gathered, carefully read, matched, compared, and organized into large themes. Each theme was then further analyzed and divided into subthemes. These were then discussed, compared with the literature, and developed. The current study draws mainly upon information that derived from documents and interviews with the MIPAD officials and civil servants.

\section{THE CASE OF E-GOVERNMENT IN GREECE}

This section describes the Greek e-government initiative. First, we present a brief historical account of the way in which the Greek public sector has been constructed. Then, we describe the establishment of Citizens Service Centers (CSCs).

\subsection{Greek Public Administration}

The Greek public sector consists of the central and local government, public and quasi-public organizations, and independent administrative authorities. The people who work in the public sector, civil servants, are permanently employed in public organizations. Additionally, there are a number of people who work on a contract basis in order to cover urgent and temporary needs. Independently of their employment status, all civil servants are legally accountable to the law (i.e., the constitution, civil servants' code).

The Greek public sector was founded in 1830s after the independence of the state from the four centuries of Ottoman subjection (Argyriadis 2000). It was modeled on the French public sector, which functioned in accordance with the principles of the Weberian bureaucracy (Argyriadis 2000; Weber 1948). Through time, the function of the Greek public sector has been pertained by hierarchical relations, affluence of rules and regulations, and an increased number of departments. Also, from its foundation until now, the public sector has displayed certain characteristics.

First, it has been the largest employer. Specifically, in the $19^{\text {th }}$ century, the government employed an increasing number of citizens in the public sector. It did so in order to address socio-economic problems, such as unemployment and poverty, that followed the war of independence (Mouzelis 1978; Tsoukalas 1986). The government continued the same practice in the 1950s. The aim at that time was to address the problem of internal immigration that civil war conditioned (Argyriadis 2000; Tsoukalas 1987). The public sector continued to expand until it reached its peak at the end of the 1980s. During that decade, the socialist government promoted the rhetoric of participation and democratization and imposed social criteria for employment in the public sector (Avgerou 2002). 
Second, the function of the public sector has been surrounded by the development and operation of client relations (Avgerou and McGarth 2007; Legg 1969; Mouzelis 1978). The latter are relationships of mutual exchanges that are developed between unequal, in terms of authorities and/or resources, parts in order to satisfy their interests (Brinkerhoff and Goldsmith 2004; Kaufman 1974; Lemarchand 1972). Client relations prevailed from the 1830s (state's independence) until now in all echelons of the public administration (i.e., between civil servants and citizens and politicians and civil servants). Many times, client relations entailed the exchange of political support for employment in the public sector. Also, client relations took various forms through time. For instance, in the $19^{\text {th }}$ century, client relations were personal and direct exchanges between local governors and citizens, whereas in the $20^{\text {th }}$ century, client relations were mediated relationships between political parties and citizens.

Third, the growth of the public sector rendered civil servants a powerful group or, as Tsoukalas (1987, p. 115) argued, "a state within the state." Every government wanted to gain civil servants' sympathy, ensuring in that way their political support. For that reason, governments were concerned that any changes they brought about wouldn't threaten the interests of civil servants. This attitude, however, triggered a chain of consequences. The favorable treatment of civil servants led to a lack of effective mechanisms to control their behavior. This in turn conditioned illegitimate phenomena such as development of client relations and corruption (Ballas and Tsoukas 2004). Also, officials' favorable treatment meant lack of effective performance measurement techniques. Officials' performance was estimated by their supervisors and as a result was highly subjective and partial (Ballas and Tsoukas 2004). Moreover, the affluence of laws in combination with their abstract and contradictory character allowed civil servants to exercise a high degree of discretion when interpreting the law. This is thought to condition arbitrariness and irresponsibility. Finally, the growth of the public sector has been accompanied by low salaries, lack of incentives, limited jurisdictions, and unclear responsibilities, which conditioned civil servants' dissatisfaction, alienation, and low morale (Argyriadis 2000; Avgerou 2002; Lipsky 1980).

It was in this context that the first steps toward the modernization of the Greek public sector were taken. At the time, various laws were passed about the introduction of management practices into the function of the public sector, privatization of public organizations, and depoliticization of employment procedure. The majority of these measures did not respond to the intended way, yet they diffused the imperative to change the public sector and paved the way to the establishment of CSCs.

\subsection{The Establishment of Citizens Service Centers}

Citizens Service Centers were established in 2002 as one-stop shops. They were developed by the Ministry of Interior, Public Administration and Decentralization (MIPAD) and they were managed by a group of officials from the MIPAD who constituted the CSCs' project team. CSCs are staffed with individuals who work on fixed term contracts, which are renewable subject to satisfactory performance. According to the law (L.3013/2002), the role of CSCs is to mediate between citizens and public organizations for the continuous and fast service of citizens. CSCs accept citizens' requests for public services, then request that they to be processed by the relevant public organizations, and 
when they have been processed, pass the outcome (such as certifications, licenses, copies of public documents, etc.) to citizens. CSCs collaborate with public organizations either through fax, e-mail, post, courier, or, mainly, the personal transfer by the CSC staff to the relevant public organization. Despite the establishment of CSCs, citizens can still turn directly to public organizations in order to submit their administrative requests.

CSCs were conceptualized by the MIPAD as an amalgamation of the best practices of the private sector. An official from the MIPAD said, "bureaucracy came to a halt...it couldn't be further improved. On the other hand, the private sector had experience, so we had to look at the practices of the private sector." In particular, CSCs adopted the branch system of the banking sector, the logistic system of automotive industry, and the customer orientation of fast-food outlets. Their function was also supported by a centralized computer system that monitored the outputs of each CSC and each CSC staff. Table 1 is a synopsis of the best practices of the private sector that were transferred to CSCs. The table is an outcome of the accounts of MIPAD officials during interviews. These practices are discussed below.

To begin with, the system of branches, which the banking sector deploys, ensures that customers submit all of their banking requests in any branch, independently of its location. In the Greek public sector, however, public organizations have been a monopoly in public service provision. Citizens are anticipated to know the variety of public services that are provided by each public organization and turn to each specialized public department in order to submit their enquiries. Yet most citizens either lack of this knowledge or are indifferent to it. Further, officials from the MIPAD argued that citizens are used to qualitative services from the private sector and expect the same quality standards from the public sector. For that reason, the MIPAD created homogeneous governmental shops across the country "that have the label of the state and within which citizens can receive any public service." These shops, CSCs, didn't substitute but supplemented public organizations. In other words, CSCs are an alternative public service provider and consequently an option to citizens.

Second, the MIPAD studied and imitated the logistic system of automotive industry. The latter partitions the production of cars, which takes place centrally, from their delivery, which is undertaken by local dealers. Similarly, the MIPAD intended through CSCs to divide the supply and provision of public services. Traditionally, civil servants came in

Table 1. The Best Practices of the Private Sector Transferred to CSCs

\begin{tabular}{|l|l|}
\hline Best Practices of the Private Sector & \multicolumn{1}{|c|}{ Practices Transferred to CSCs } \\
\hline Banking sector: system of branches & $\begin{array}{l}\text { Multiple public services from single, } \\
\text { homogeneous points }\end{array}$ \\
\hline Automotive industy: logistics system & $\begin{array}{l}\text { Supply versus provision } \\
\text { Mediated public service provision }\end{array}$ \\
\hline Fast-food chains: customer service & Standardization of administrative procedures \\
\hline $\begin{array}{l}\text { Information and communication } \\
\text { technologies (ICTs) }\end{array}$ & Electronic performance monitoring system \\
\hline
\end{tabular}


direct contact with citizens and were solely responsible for public service provision. With the establishment of CSCs, however, they are rendered "suppliers" of public services; their role is restricted to checking and processing documentation and issuing public documents or services (certifications, licenses, social benefits, etc). Also, their new role presupposes various responsibilities: civil servants are anticipated to be professionals when they process citizens' cases, experts in and responsible for their work object. They also have to be quick and effective, to be able to explain in a simple and understandable way anything necessary to CSCs' staff, and to care for the results of their actions.

Third, the customer service of fast food outlets was used as a prototype for the development of CSCs. As an official from the MIPAD argued, fast food outlets are "homogeneous shops...have a recognizable label and a standard menu that people know." This allows them to provide food of standard type, quantity, and quality. Drawing upon the fast-food outlets the officials from the MIPAD decided to "create shops of McDonalds' type" in which standardized services would be provided. Specifically, the MIPAD simplified and standardized 1,000 administrative procedures in order to eliminate any unnecessary information and documentation from the process of public service provision. Because of standardization, citizens would also receive public services or documents instantly, without queues and time lags. The standardization of administrative procedures was accompanied by a number of regulations that required civil servants to adopt the standardized procedures and work in collaboration with CSCs' staff for the quick processing of citizens' cases. Civil servants are also forbidden from requesting different documents from those stipulated by standardization and given a maximum time limit of 50 days to process the requests submitted by CSCs' staff. Noncompliance with the above obligations is thought to be a breach of civil servants' duties and is legally punishable.

Further, the establishment of CSCs was accompanied by the development of a central computer system, in which updated administrative information, administrative forms, and general details about citizens is kept. CSCs' staff use the system on a daily basis by uploading citizens' requests and downloading administrative forms and information. Also, the system incorporates an MIS application that keeps daily statistics about the outputs of each CSC and staff, such as their complete and pending requests and the time that it takes to deliver a submitted request back to citizens (response time). These statistics are solely available to CSCs' project team in the MIPAD in order to measure the productivity of CSCs' staff and civil servants. The productivity of CSCs' staff is directly estimated through the credentials that staff has to log into the system and is calculated based upon the number of requests that CSCs' staff submit per day. The productivity of civil servants refers to the time that it takes them to process citizens' requests. Yet, because few public organizations run information systems that are connected to CSCs' system, civil servants' productivity is indirectly estimated through the pending requests and response time of CSCs. These indicators show, respectively, which public organizations fail to process citizens' requests and how long it takes them to process and provide the public service or document back to CSCs' staff.

For the officials of the MIPAD, the MIS constitutes a great innovation in the public sector. This is because it provides, for the first time, objective information to estimate civil servants' performance based upon their outputs: "technology gives the opportunity for the first time to control public administration....In the past, performance was measured by supervisors and, thus, all estimations were subjective and biased." Indeed, out 
of this information, the CSCs' project team constructed average performance indicators. The latter were then the criterion against which actual performances were compared and, in case of deviations, decisions for intervention and correction were made. For instance, the MIPAD suspended the function of some CSCs that had low productivity and intervened into the function of various public organizations in order to advise them on how to become more effective. Finally, CSCs' computer system was perceived as being an intermediary that would unite, in the long run, CSCs with the "traditional" public sector.

\section{ANALYSIS AND DISCUSSION}

This section discusses the changes that CSCs induced to civil servants' practices along with their implications. As we shall see, CSCs changed civil servants' work roles, nature of work, forms of knowledge, mode of control, and source of accountability. These types of changes are illustrated in Table 2 and constitute the analytical framework for the discussion that follows.

First, the establishment of this one-stop shop split the (previously united) process of public service provision into two, processing and delivery, and attributed the role of suppliers to civil servants. This partitioning would achieve two results: (1) the elimination of the contact point between civil servants and citizens would reduce any opportunities for corruption and client relations (Kumar and Best 2002); (2) the supplyprovision split would bring work efficiencies. The reduction in the number of citizens that turn to public organizations would free up more time for civil servants to focus solely on their work object. Because of that, the supply-provision split could also be approached as an effort to increase the status of civil servants, which historically has been devaluated, as a professional group.

Second, the establishment of CSCs influenced the nature of civil servants' work. The establishment of CSCs constructed a quasi-market in which civil servants, who used to be a monopoly in public service provision, would compete with CSCs' staff for the provision of public services to citizens. Specifically, civil servants would need to promote their competitive advantage so as to create, maintain, and expand the number of citizens that still turn to them. Their clientele, rather than their monopoly, constitutes the source of their legitimacy. Moreover, the development of a quasi-market is under-

Table 2. The Types of Changes to Work Practices Brought by E-Government

\begin{tabular}{|l|l|}
\hline \multicolumn{1}{|c|}{ Types of Changes } & \multicolumn{1}{c|}{ Chang } \\
\hline Work role & Officials $\rightarrow$ Suppliers \\
\hline Nature of work & Monopoly $\rightarrow$ Quasi-market \\
\hline Forms of knowledge & Implicit knowledge $\rightarrow$ Explicit knowledge \\
\hline Mode of control & $\begin{array}{l}\text { Periodic, legal, and hierarchical } \rightarrow \text { Constant, individualistic, } \\
\text { and output-oriented }\end{array}$ \\
\hline Source of accountability & Law and hierarchy $\rightarrow$ output orientation \\
\hline
\end{tabular}


pinned by the idea that civil servants are neither guards of the public interest nor public service providers, but mere entrepreneurs. This is manifested by the fact that civil servants have to process information within specific time limits and respond to performance averages, which are electronically monitored by the ministry. Further, the development of a quasi-market in the provision of public services aimed to limit the authorities of civil servants by diffusing part of them (e.g., the right to deliver public services) to CSCs' staff(Bovens and Zouroudis 2002). In that way, civil servants' opportunities to develop client relations with citizens would be considerably reduced (Kumar and Best 2002).

What is more, the aim of standardizing administrative procedures was to transform civil servants' abstract, idiosyncratic and tacit knowledge into standardized and explicit knowledge. This is mainly because it is anticipated that civil servants will draw upon the standardized procedures, rather than their knowledge and judgment, in order to make decisions (Bovens and Zouroudis 2002), eliminating the autonomy of civil servants to freely exercise discretion and leading, contrary to what was previously said, to the deprofessionalization of their occupation.

In addition, the establishment of CSCs introduced new, managerial in nature, forms of power. Specifically, the electronic performance monitoring system that was deployed in the Greek one-stop shop displaced the periodic, legal, and hierarchical mode of control and imposed one that is constant, individualistic, and output-oriented. The performance monitoring system constituted a panopticon (Foucault 1977) in public service provision (Zhang 2002). The continuous monitoring, along with the development of average performances, was intended to impose the imperative for continuous self-control on civil servants. This is because their awareness of being the object of monitoring would make civil servants internalize the performance averages and continuously strive to become better performers. Further, by rendering performance visible, inefficiencies would be corrected and arbitrariness and civil servants' autonomy would be eliminated.

Moreover, the standardization of administrative procedures was intended to normalize civil servants' conduct. Standardization would eliminate any fragmentation or differentiation in the processing and provision of public services by bringing each public service down to its necessary documentation/information. In that way, public service provision became a preprocessed and predictable activity that could be undertaken by anyone who lacked work experience and/or knowledge on the function of the public sector (Bovens and Zouroudis 2002). Also, by fostering homogeneity, the aim of standardization was to obstruct civil servants' autonomy, which, as the historical account indicated, was for many years beyond the control of the government. In that way, the well-established problem of client relations that civil servants typically developed with citizens or political parties would also be eliminated. So, although we agree with Purnendra (2002) that e-government shakes the established power relations in the public sector, we argue in line with Zhang (2002) that, rather than providing autonomy, egovernment is a means for delicate and constant exertion of power over officials.

Finally, the establishment of CSCs influenced officials' source of accountability. Typically, officials' source of accountability was the law and the hierarchy. The establishment of CSCs added a further source of unaccountability that is output-oriented in nature. Specifically, officials are rendered responsible for quickly processing citizens' requests and effectively collaborating with the staff from the one-stop shop. This orientation toward outputs is justifiable within the Greek public sector that had long enabled 
officials to be politically partisian and exercise unlimited discretion. Yet, we need to anticipate that by paying attention solely to quantifiable activities (for instance, the number of citizens that are served or the time to process citizens' requests), important prerequisites for public service provision, such as human judgement and sensitivity, are excluded.

The above types of changes to officials' practices similarly influence the process of public service provision. Specifically, e-government renders the process of public service provision predictable, quantifiable, and standardized or, as Ritzer (1993) and Garson (1988) would say, intends for the McDonaldization of public service provision. First, e-government eliminates personal contact and renders public service provision a mediated procedure. It does so by standardizing public services and by treating citizens as cases that need to be fit into predefined categories (Ciborra 2005; Fountain 2001). Moreover, public services are provided in a fast, standardized but hardly customized way by multiple public service providers, which compete in (quasi) internal markets. Further, we can speculate that these effects influence citizens who, far from being considered as the locus of social and political rights, are recast as responsible individuals that are aware of their needs, anticipate fast and qualitative service, and are able to make effective choices among competing public service providers.

Overall, the type and scope of changes that e-government and one-stop shops bring about to officials' practices are contingent and situated rather than definite (Yildiz 2007). They depend, not least, upon the historical context within which e-government is initiated. History, as the case illustrated, doesn't only provide the rationale upon which e-government draws but also opens up avenues for comprehending not only what egovernment is (and is not) but also what e-government does. Specifically, our findings indicate that e-government initiatives bring about five types of changes to the nature of work, roles, mode of control, knowledge, and source of accountability of officials, and similarly influence the provision of public services. These changes, as they are encapsulated in Table 2, constitute a methodological framework, which, together with the history of each public sector, can assist governments and researchers in the conceptualization of the (potential) consequences, risks, and challenges of e-government.

\section{CONCLUSION}

The paper discussed the changes that e-government brings about to civil servants' practices by drawing upon a Greek one-stop shop. As the study indicated, e-government reorganizes the public sector in accordance with the best practices of the private sector; for instance, through internal markets, service standardization, performance measurement, and electronic surveillance. At the same time, e-government challenges the power relations that are embedded in the public sector. It attributes new roles and authorities to public officials and in doing so directs their conduct toward achieving and performing. Further, it increases the sources of accountability and control by focusing not on the process but the outcomes of public service provision, limiting in that way the autonomy and discretion of public officials. Moreover, the initiation of e-government intends to address well-established problems of bureaucracies, in our case client relations and accountability. These effects on public service provision are not deterministic but dependent upon the history of each public sector and the way in which e-government is 
conceptualized and carried out by each government and why. This indicates that whether or not and how e-government influences officials' conduct and, as a result, public service provision is first and foremost a political question.

\section{Acknowledgments}

The author wishes to express her gratitude to Dr. Niall Hayes and Professor Lucas Introna for their support in the completion of this article.

\section{References}

Argyriadis, D. "Facets of Administrative Change in Greece," in Reports of Experts on Public Administration 1950-1998, A. Makrydimitris and N. Michalopoulos (eds.), Athens: Papazese Publications, pp.373-428 (in Greek; first published in 1970).

Avgerou, C. 2002. Information Systems and Global Diversity, Oxford: Oxford University Press. Avgerou, C., and McGarth, K. 2007. "Power, Rationality and the Art of Living Through SocioTechnical Change,” MIS Quarterly (31:2), pp. 295-315.

Ballas, A., and Tsoukas, H. 2004. "Measuring Nothing: The Case of the Greek National Health System," Human Relations (57:6), pp. 661-690.

Basu, S. 2004. "E-Government and Developing Countries: An Overview," International Review of Law Computers (18:1), pp. 109-132.

Berger, P., and Luckmann, T. 1966. The Social Construction of Reality: A Treatise in the Sociology of Knowledge, New York: Penguin Books.

Blau P. 1970. "Weber's Theory of Bureaucracy," in Max Weber, D. Wrong (ed.), Englewood Cliffs, NJ: Prentice Hall

Bloomfield, B., and Hayes, N. 2004. "Modernisation and the Joining-Up of Local Government Services in the UK: Boundaries, Knowledge and Technology," paper presented at Information, Knowledge and Management: Reassessing the Role of ICTs in Private and Public Organizations, Bologna, Italy, March 3-5.

Brinkerhoff, D., and Goldsmith, A. 2004. "Good Governance, Clientelism and Patrimonialism: New Perspectives on Old Problems," International Public Management Journal (7:2), pp. 163-185.

Bovens, M., and Zouroudis, S. 2002. "From Street-Level to System-Level Bureaucracies: How Information and Communication Technology is Transforming Administrative Discretion and Constitutional Control," Public Administration Review (62:2), pp. 174-184.

Campbell, C. 1993. "Public Service and Democratic Accountability," in Ethics in Public Service, R. Chapman (ed.), Edinburgh: University Press, pp.111-133.

Chadwick, A., and May, C. 2003. "Interaction between States and Citizens in the Age of the Internet: E-Government in the United States, Britain and the European Union," Governance: An International Journal of Policy, Administration and Institutions (16:2), pp. 271-300.

Ciborra, C. U. 2003. "Unveiling E-Government and Development: Governing at a Distance in the New War," working paper 126, Lancaster University (http://is2.lse.ac.uk/ wp/pdf/WP126.PDF).

Ciborra, C. U. 2005. "Interpreting E-Government and Development: Efficiency, Transparency or Governance at a Distance?," Information Technology and People (18:3), pp. .260-279.

Clarke, J., and Newman, J. 1997. The Managerial State: Power, Politics and Ideology in the Remaking of Social Welfare, London: Sage Publications.

Cordella A. 2007. "E-Government: Towards the E-Bureaucratic Form?," Journal of Information Technology (22), pp. 265-274. 
Cowell, R., and Martin, S. 2003. "The Joy of Joining-Up: Modes of Integrating the Local Government Modernization Agenda," Environment and Planning C: Government and Policy (21:2), pp. 159-179.

Davison, R., Wagner, C., and Ma, L. 2005. "From Government to E-Government: A Transition Model," Information Technology and People (18:3), pp. 280-299.

du Gay, P. 2000. In Praise of Bureaucracy: Weber, Organization, Ethics, London: Sage Publications.

Farrell, C., and Morris, J. 2003. "The Neo-Bureaucratic State: Professionals, Managers and Professional Managers in Schools, General Practices and Social Work," Organization (10:1), pp. 129-156.

Foucault, M. 1977. Discipline and Punish: The Birth of the Prison, London: Penguin Books.

Fountain, J. 2001. "Paradoxes of Public Sector Customer Service," Governance: An International Journal of Policy and Administration (14:1), pp. 55-73.

Garson, B. 1988. The Electronic Sweatshop: How Computers Are Turning the Office of the Future into the Factory of the Past, New York: Simon and Schuster.

Gil-Garcia, R., Chengalur-Smith, I., and Duchessi, P. 2007. "Collaborative E-Government: Impediments and Benefits of Information-Sharing Projects in the Public Sector," European Journal of Information Systems (16), pp. 121-133.

Goodsell, C. 2005. "The Bureau as Unit of Governance," in The Values of Bureaucracy, P. du Gay (ed.), Oxford, UK: Oxford University Press, pp. 17-40.

Hazlett, S., and Hill, F. 2003. "E-Government: The Realities of Using IT to Transform the Public Sector," Managing Service Quality (13:6), pp. 445-452.

Heeks, R. 2002. "E-Government in Africa: Promise and Practice," Information Polity (7:2/3), pp. 97-114.

Heeks, R., and Bailur S. 2007. “Analyzing eGovernment Research: Perspectives, Philosophies, Theories, Methods and Practice," Government Information Quarterly (24:2), pp. 243-265.

Ho, T. A. 2002. "Reinventing Local Governments and the E-Government Initiative," Public Administration Review (62:4), pp. 434-444.

Hoggett, P. 1996. "New Modes of Control in the Public Service," Public Administration (74:1), pp. 9-32.

Hood, C. 1991. “A Public Management for All Seasons?," Public Administration (69:1), pp. 3-19.

Huang, Z., and Bwoma, P. 2003. “An Overview of Critical Issues of E-Government,” Issues of Information Systems (4:1), pp. 164-170.

Illsley, B. M., Lloyd, M. G., and Lynch, B. 2000. "From Pillar to Post? A One Stop Shop Approach to Planning Delivery," Planning Theory and Practice (1:1), pp. 111-122.

Kaufman, R. 1974. "The Patron-Client Concepts and Macro-Politics: Prospects and Problems," Comparative Studies in Society and History (16:3), pp. 284-303.

Kumar, R., and Best, M. 2006. "Impact and Sustainability of E-Government Services in Developing Countries: Lessons Learned from Tamil Nadu, India," The Information Society (22:1), p.p. 1-12.

Kunstelj, M., and Vintar, M. 2004. "Evaluating the Progress of E-Government Development: A Critical Analysis," Information Polity (9), pp. 131-148.

Legg, K. 1969. Politics in Modern Greece, Stanford, CA: Stanford University Press.

Lemarchand, R., and Legg, K. 1972. "Political Clientelism and Development: A Preliminary Analysis," Comparative Politics (4:2), pp. 149-178.

Lenk, K. 2002. "Electronic Service Delivery: A Driver of Public Sector Modernization," Information Polity (7), pp. 87-96.

Lipsky, M. 1980. Street-Level Bureaucracy: Dilemmas of the Individual in Public Services, New York: Russell Sage Foundation.

Martin, B., and Byrne, J. 2003. "Implementing E-Government: Widening Lens," Electronic Journal of E-Government (1:1), pp. 11-22. 
Minson, J. 1998. "Ethics in the Service of the State," in Governing Australia: Studies in Contemporary Rationalities of Government, M. Dean and B. Hindess (eds.), Cambridge, UK: Cambridge University Press, pp. 47-69.

Moon, J. 2002. "The Evolution of E-Government among Municipalities: Rhetoric or Reality?," Public Administration Review (62:4), pp. 424-433.

Mouzelis, N. 1978. Modern Greece: Facets of Underdevelopment, Athens: Eksantas (in Greek).

Purnendra, J. 2002. “The Catch-Up State: E-Government in Japan,” Japanese Studies (22:3), pp. 237-255.

Ritzer, G. 1993. The McDonaldization of Society: An Investigation into the Changing Character of Contemporary Social Life, Thousand Oaks, CA: Pine Forge Press.

Roche M. 2004. "Complicated Problems, Complicated Solutions? Homelessness and Joined-Up Policy Responses," Social Policy and Administration (38:7), pp. 758-774.

Suchman, L. 1987. Plans and Situated Actions: The Problem of Human-Machine Communication, Cambridge, UK: Cambridge University Press.

Tan, C., and Pan, S. 2003. "Managing E-Transformation in the Public Sector: An E-Government Study of the Inland Revenue Authority of Singapore," European Journal of Information Systems (12:4), pp. 269-281.

Tsoukalas, K. 1986. Social Development and State: The Composition of Public Space in Greece ( $2^{\text {nd }}$ ed.), Athens: Themelio (in Greek).

Tsoukalas, K. 1987. State, Society, Employment in Post-War Greece ( $2^{\text {nd }}$ ed.), Athens: Themelio (in Greek).

Turner, P., and Higgs, G. 2003. "The Use and Management of Geographic Information in Local E-Government in the UK," Information Polity (8:3/4), pp. 151-165.

Vintar, M., Kunstelj, M., Decman, M., and Bercic, B. 2003. "Development of E-Government in Slovenia," Information Polity (8:3/4), pp. 133-149.

von Haldenwang, C. 2004. "Electronic Government (E-Government) and Development," European Journal of Development Research (16:2), pp. 417-432.

Weber, M. 1948. "Bureaucracy," in From Max Weber: Essays in Sociology, H. H. Gerth and C. W. Mills (eds.), London: Routledge.

Wilkins, P. 2002. "Accountability and Joined-Up Government," Australian Journal of Public Administration (61:1), pp. 114-119.

Yildiz, M. 2007. "E-Government Research: Reviewing the Literature, Limitations, and Ways Forward," Government Information Quarterly (24), pp. 646-665.

Zhang, J. 2002. "Will the Government 'Serve the People'? The Development of Chinese eGovernment," New Media and Society (4:2), pp. 163-184.

\section{About the Author}

Dimitra I. Petrakaki is a doctoral student at Lancaster University (UK) and a lecturer in Information Systems at the University of Wolverhampton (UK). Her research interests revolve around the relation of knowledge and power in the initiatives of public sector reformation and egovernment. She can be reached at d.petrakaki@lancaster.ac.uk. 